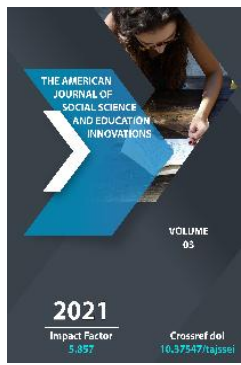

Journal Website: http://theamericanjour nals.com/index.php/taj ssei

Copyright: Original content from this work may be used under the terms of the creative commons attributes 4.0 licence.

\section{Uzbekistan's Cooperation On Sustainable Development}

F.Ziyayev

"Social Sciences" Department , TMI , Uzbekistan

Xolbekov A

Senior Teacher, "Social Sciences" Department, TMI, Uzbekistan

Avalova G.

Senior Teacher, "Social Sciences" Department, TMI, Uzbekistan

\title{
ABSTRACT
}

"From the first days of independence of the Republic of Uzbekistan, a well-thought-out foreign policy has been consistently implemented," Shavkat Mirziyoyev said. "In his time, the centuries-old history, culture, traditions and values of our people, noble aspirations and interests are embodied ${ }^{1}$.

\section{KEYWORDS}

United States, Russia, China, Turkey, Japan, South Korea and the European Union, investment, financial, cultural-humanitarian and security relations

${ }^{1}$ Address Of The President Of The Republic Of Uzbekistan Shavkat Mirziyoyev To The Oliy Majlis. 29.12.2020 
In his next appeal to the Oliy Majlis, President Shavkat Mirziyoyev noted that Uzbekistan's foreign policy will be consistently continued from now on, without withdrawing from these printouts. At the same time, special emphasis was placed on the need for further strengthening and development of tradeeconomic, investment, financial, culturalhumanitarian and security relations with the developed countries of the world-the United States, Russia, China, Turkey, Japan, South Korea and the European Union.

In accordance with the "concept of foreign political activity" of the Republic of Uzbekistan, one of the main directions of the foreign policy of the Republic is cooperation with the United States. The Uzbek-US relations are based on mutual respect and consideration of each other's interests, and the parties have close positions on a number of international and regional issues, including the strengthening of peace and stability in Central Asia and Afghanistan, are the main directions of mutual cooperation.

The tasks identified in the priorities of the strategy of action in the field of deep thoughtout, mutually beneficial and practical foreign policy are of great importance in achieving the development of Uzbekistan. It is known that our country conducts effective cooperation with all foreign countries and the world community in its foreign policy activities based on the interests of our people and our country and on open, friendly and pragmatic principles.

In addition, Uzbekistan's trade and economic relations with the United States are increasingly developing. Currently, there are a number of world-renowned big companies operating in Uzbekistan, such as General Motors Powertrain Uzbekistan, Exxon Mobil, $\mathrm{CNH}$ Industrial, Coca-Cola, Hyatt, Hilton, John Deere, Honeywell, Caterpillar and others.

Large-scale cooperation with the Russian Federation is based on agreements on strategic cooperation and allied relations signed between the two countries. At the moment, bilateral trade and economic relations with the Russian Federation are also developing at a rapid pace. In this regard, it is worth acknowledging that the Russian Federation occupies a leading place among our foreign trade partners.

Mutually beneficial cooperation with China is also based on the proximity of the parties ' views on terrorism, extremism, drug trafficking, illegal arms trade and other threats of security. In addition, Uzbekistan is based on the principles of mutual cooperation in strengthening strategic cooperation with China, conducting extensive trade-economic, investment and financial cooperation. Today, Uzbekistan and China are actively developing cooperation on various projects, above all, the implementation of projects in the field of high technologies. A number of Chinese companies are actively involved in the exploration and excavation of hydrocarbon deposits on the territory of the Republic. Also, many enterprises with the participation of Chinese capital are operating effectively in our country.

Economic and political relations with the Turkish state, which is considered one of the major trade and economic partners of Uzbekistan, continue to strengthen. Regular political consultations are held between the ministries of foreign affairs of both countries. At the same time, relations between the two 
countries in the cultural, humanitarian, educational and tourism spheres are steadily developing.

Cooperation with Japan is based on the legal basis of the joint statement on friendship, strategic partnership and Cooperation signed between Uzbekistan and Japan and the joint statement on the deepening and expansion of strategic partnership. Meanwhile, constant political consultations between the ministries of foreign affairs of the two countries are yielding fruitful results. In addition, Japan is constantly providing financial and technical assistance to Uzbekistan. Thanks to this support, a number of socially significant and infrastructure projects have been implemented in health, education, transport, telecommunications and other spheres in Uzbekistan. In addition, the regional offices of the Japanese agency for international cooperation (JICA) and the Japanese Foreign Trade Organization (JETRO) are functioning effectively in our country. In addition, the production of buses and trucks has been launched in cooperation with UzAuto and Isuzu of Uzbekistan.

President of Uzbekistan Sh.Mirziyoev's statement on the comprehensive expansion of strategic cooperation, adopted on 22-25 November 2017 on the results of his state visit to the Republic of Korea, is being continued. More than 20 agreements at the state, government and interagency levels were also signed within the framework of this visit. In addition, a total of 64 documents in tradeeconomic, financial-technical and other spheres worth more than 10 billion dollars have been signed, of which 4 billion dollars constitute direct Korean investments in the economy of Uzbekistan. Also, the parliamentary exchange between the two countries is developing successfully. In the National Assembly of the Republic of Korea there is a special group on cooperation with Korea in the Friendship Association "KoreaUzbekistan" and the Legislative Chamber of the Oliy Majlis of the Republic of Uzbekistan. Constant political consultations are being held between the foreign affairs agencies of the two countries. In addition, the Republic of Korea is the country that occupies the highest place among the trade partners of Uzbekistan in Asia and the Pacific. At the same time, the joint government of trade and economic cooperation is successfully operating. It is also worth noting the active participation of South Korean business circles in the creation of the Navoi free industrial economic zone in Uzbekistan.

The agreement on partnership and cooperation forms the solid legal basis of our effective cooperation with the European Union, and on the basis of this document, effective multilateral relations - the Cooperation Council, the Parliamentary Cooperation Council and other structures-are effectively functioning. In addition, our country is actively working on further development of cooperation with the European bank for reconstruction and development within the framework of the large - scale investment program of the Uzbek-European partnership.

Proceeding from the above, Uzbekistan is recognized as a strategic and reliable partner by international organizations and countries as a result of its initiatives and practical efforts in solving global and global problems. In particular, on December 12, 2018 at the plenary session of the UN General Assembly adopted a special resolution called "Enlightenment and religious tolerance". The project of this document was developed by Uzbekistan and unanimously supported by all UN member states. It should be noted that the adoption of this historical resolution was a 
practical expression of the initiative put forward by President Shavkat Mirziyoyev at the 72nd session of the UN General Assembly in September 2017 in New York.

Alternatively, in October this year, Uzbekistan was first elected as a member of the UN Human Rights Council. For the purpose of further development of this sphere in our country, the national strategy on human rights and the "road map" on its implementation have also been approved. At the time of these initiatives, principles on ensuring equality of citizens of our country play an important role in ensuring guaranteed human rights in the Constitution of the Republic of Uzbekistan, regardless of gender, race, nationality, language, religion, social origin.

"From now on, we also rely on strategic tasks and priority directions established in the concept of foreign political activity of the Republic of Uzbekistan in the conduct of our foreign policy. We are always committed to the path chosen by US, based on peacefulness, aimed at solving the conflicts and conflicts that arise only by peaceful, political means," the head of state said.

The fact that we do not join any militarypolitical blocs, do not allow the location of military bases and facilities of other countries on the territory of Uzbekistan, the participation of our military in foreign operations, remains a decisive political position of our state.

In the spirit of openness and benevolence towards all our partners in the field of foreign policy, we conduct pragmatic policy, noted the president of our country Shavkat Mirziyoyev.

Uzbekistan highly appreciates fruitful relations with the European Union. A solid legal basis for this is an agreement on partnership and cooperation. On the basis of this document, impressive multilateral relations - the Cooperation Council, the Parliamentary Cooperation Council and other structures are functioning.

Large-scale relations between Uzbekistan and France are consistently developing. As a permanent member of the Security Council of the United Nations, France supported Uzbekistan's initiative to create a nuclear-free zone in Central Asia.

It is worth noting the participation of French companies in the economy of the country, the growth of bilateral trade. The structure of the French Development Agency began to work in Uzbekistan. Cooperation in the cultural and humanitarian sphere is an important direction of mutual relations. The activity of the "French alliance"in Uzbekistan is supported for the thorough study of the French language by our youth.

Japan is a strategic partner with a special place in Uzbekistan's foreign policy. Japan is not only economically developed, but also a powerful state that plays an increasingly important role in solving global problems. Prime Minister Sindzo Abe's official visit to Uzbekistan in October 2015 was a new step towards developing our multifaceted partnership in the spirit of strategic partnership.

Uzbekistan is ready to jointly implement projects and programs on the further expansion of investment and financial and technical cooperation with Japan, on the future sectors of high technologies, transport infrastructure, communications, mechanical engineering. It is planned to launch the Uzbek - Japanese Youth Innovation Center at Tashkent State Technical University named 
after Islam Karimov. This center will be of great importance in the broad application of the most advanced innovative ideas and technologies to industrial sectors and in the development of the industry to a new level.

The peoples of Uzbekistan and Egypt are connected by centuries-old ties, common cultural values. Our people are equally proud of the rich scientific heritage of the great Uzbek nation Ahmed Fergani, who created a unique device measuring the volume of water in the Nile River - the nilomer equipment. It is an expression of the high respect of the Egyptian people to the Uzbek people by the symbol of the majestic monument erected in Cairo, the city of alloma. Uzbekistan is interested in taking traditional friendly cooperation with the Arab Republic of Egypt to a new level, which has a great reputation not only in the region, but also in the Arab and Muslim worlds.

Turkey is one of the first countries to recognize the independence of Uzbekistan. President of Uzbekistan Shavkat Mirziyoyev and President of Turkey Recep Tayyip Erdogan's talks in Samarkand started the process of bringing the relations between the countries to a new level.

Uzbekistan adopted a practical action plan covering all spheres of implementation of bilateral agreements, namely a specific "road map". Special attention is paid to the activities of the government commission on trade and economic cooperation in increasing the volume of mutual trade and implementing promising investment projects.

The agreements reached by Uzbekistan in trade and investment, tourism, transport communications, logistics and other spheres with Turkey serve as a solid basis for further development of cooperation.
Cooperation with the kingdom of Saudi Arabia is of great importance for Uzbekistan. Taking into account the increasing number of our compatriots who want to perform Hajj in recent years, the number of pilgrims from our country has increased in 2017.

Uzbekistan attaches particular importance to relations with Saudi Arabia within international organizations, including with the Organization of Islamic Cooperation. At present, Uzbekistan is the chairman of the Council of foreign ministers of this organization. Uzbekistan remains a supporter of further activation of mutually beneficial and long-term relations with Saudi Arabia in the trade-economic, investment and financial spheres.

In common words, the embodiment of the principles and tasks established in our Constitution is manifested as a basis for the positive result of the regional and global foreign policy pursued by Uzbekistan today. Most importantly, the country's foreign policy serves to ensure the highest interests, wellbeing and security of the state and the people.

The foreign policy of Uzbekistan is carried out in full compliance with the basic legal principles enshrined in the Charter of the United Nations and our Constitution and international obligations assumed by our country.

\section{REFERENCES}

1. Councils B.Ya., Yakovlev S.A. System Modeling: Textbook. for universities. 4th ed., $M$.: Higher. shk., 2017 .-- 343 p.

2. Kisil M.V. The quality of higher education as a subject of philosophical analysis. Dissertation for the degree of candidate of philosophical sciences in specialty 09.00.10. - "Philosophy of Education". - 
Institute of Higher Education of the Academy of Pedagogical Sciences of Ukraine. - Kiev, 2008.

3. Sidorenko A.L. External independent assessment in Ukraine took place // Bulletin of testing and monitoring in education. - 2008. - No. 9. - S. 13-15.

4. Redden E. Access and Equity: A Comparative Perspective. Inside Higher Education. - 2008. m March 17. // [Electronic resource]. Available at: http://insidehighered.com/news/2008/03/ 17/fulbright.

5. Belyakov A.A. Implementation of the ideas of the Bologna process: what is missing in Ukraine // Scientific notes of the KROK University. - 2008. m Issue. 18. T. 1. - S. 50-58.

6. Annikova N.A. The quality of education in Russian higher education: socio-cultural reference points of transformation. Dissertation for the degree of candidate of sociological sciences. Novocherkassk, 2006 .- 156 p.

7. Kagan M.S. Philosophy of culture. - SPb., $1996 .-354$ p.

8. Gershunsky B.S. Philosophy of Education for the 21st Century. - M., - 1998 .-- 478 p.

9. Zimnyaya I.A. General culture and social and professional competence of a person // Higher education today. - 2005. - No. 11. - S. 19-27.

10. Yakovleva T.V. Model of the quality of higher education // Problems of education in modern Russia and the post-Soviet space. - Penza, 2004 -- 343 p.

11. Khomeriki, EA Main points of a sociological approach to modeling the quality of higher education. - 2013. - No. 11 (58). - S. 755-759. 